\title{
The Efforts Of Sharia Micro Financial Institutions In Increasing Community Income (Case Study Of Bank Wakaf Mikro Honai Sejahtera Papua)
}

\author{
Shimah Fauziah Yeubun1, M. Anang Firdaus ${ }^{2}$, Fachrudin Fiqri \\ Affandy ${ }^{3}$ \\ 1,2,3nstitut Agama Islam Negeri Fattahul Muluk Papua, Indonesia. \\ zhimafauzia@gmail.com
}

\begin{abstract}
Purpose - This study aims to determine and analyze the effort of the Honai Prosperous Micro Waqf Bank in Papua in increasing community income in Heram District, Jayapura, Papua Province. Micro Waqf Bank is one of the government programs for low-scale communities.

Method - This research uses a qualitative method with a case study approach. Primary data are collected from several informants who have related duties and functions such as managers, boarding school leaders, and customers from the Honai Sejahtera Micro Waqf Bank. While secondary data includes data from documents, literature, and academic studies and research. The data that has been collected is then processed and analyzed using a field analysis approach from Miles and Huberman.

Result - The results of this study indicate that Honai Sejahtera Micro Waqf Bank improve the communities' income in Heram District by providing a loan for business capital using the Qardh. Besides that, the community felt the positive impact of their existence.

Implication - Local Governments need to work together with LKMS to empower communities to escape poverty.

Originality - This research focuses on increasing people's income through Islamic Microfinance Institution (LKMS) in Papua Province which has never been studied previously.
\end{abstract}

Keywords: Islamic Microfinance Institutions; Income; BankWakaf Micro. 
Shimah Fauziah Yeubun, M. Anang Firdaus, Fachrudin Fiqri Affandy

\section{Introduction}

Indonesia currently still has the problem of poverty and inequality, which are the most complicated problems that occur at every level of society, especially those in rural areas. Data from the Central Statistics Agency (BPS) for 2017 shows the number of poor people (people with per capita expenditure per month below the poverty line) in Indonesia as many as 26.58 million people or around $10.12 \%$. Meanwhile, inequality is still very high, namely in the range of 0.3910 (Badan Pusat Statistik, 2017). This shows that poverty is the main problem currently hitting the Indonesian nation at both the national and provincial levels. Many poverty programs have also been implemented, but they have not had much success.

One of the problems experienced by Indonesia for a long time is the high rate of poverty. Since 1990 until now, the problem of poverty has been strongly influenced by economic conditions, one of which is the deteriorating macroeconomic factors that have resulted in an economic crisis. The economic crisis that hit Indonesia in 1998 was preceded by a monetary crisis which resulted in a decline in international confidence in Indonesia. Another impact of the 1998 crisis was the weakening of the rupiah exchange rate against the dollar and high inflation. This has resulted in the weakening of people's purchasing power because at that time the price of many goods was going up uncontrollably and the cost of living was getting higher (Afendi, 2018).

The concept of empowerment develops from the reality of individuals or communities who are powerless or those who are weak (powerless). Powerlessness or weakness in the aspects of knowledge, experience, attitudes, skills, venture capital, networking, enthusiasm, hard work, persistence and other aspects. Weaknesses in various aspects are what cause dependency, powerlessness and poverty (Penina, 2019). Community empowerment is a form of human-centered development. Community empowerment is also a form of development that is planned, in accordance with the potentials, problems and needs of the community. Empowerment is aimed at making 
The Efforts Of Sharia Micro Financial ...

people capable of empowerment, competitiveness, and towards independence (Noor, 2011).

This empowerment was born to change the community's economy from insufficient to sufficient. One form of the ummat empowerment program is to develop entrepreneurship developed by the small people in this case called UKM. In an effort to encourage community empowerment, especially people with lower middle income and micro, small and medium enterprises (MSMEs), comprehensive support from financial institutions is needed (OJK, 2020). So far, MSMEs have been constrained by access to funding to formal financial institutions. To overcome this obstacle, in society many non-bank financial institutions have grown and developed which carry out business development services and community empowerment, either established by the government or the community.

The Financial Services Authority (OJK) sees opportunities for empowering the poor through microeconomic programs and mentoring, both mentoring prospective customers or customers as well as mentoring these institutions (Uci, 2018). The Financial Services Authority (OJK) through this Micro Waqf Bank institution facilitates the community in fulfillment and for the poor with the criteria of poor people who have met their basic needs, there can be a business, for example. Then have a productive business. Or now there is a business but lack of capital, but have a passion for work. Islam is a universal religion, regulating all aspects that pertain to life, especially in the economic field. This has now become the starting point for the development of Islamic or sharia economics. (Divine \& Afendi, 2019)

This institution also has the status of a sharia microfinance institution that is licensed and supervised by the same as other financial institutions. To expand financial access for small communities throughout Indonesia in 2019 the OJK also established the first Micro Waqf Bank in Papua, namely the Honai Sejahtera Papua Micro Waqf Bank, which is located at the Yaa Bunayya Islamic Boarding School, Yoka Village, Jayapura, Papua. 
Bank Wakaf Mikro (BWM) Honai Sejahtera is the first Islamic microfinance institution in Papua, which was initiated by the National Amil Zakat Institute (LAZNAS) and PT.Astra Internasional Tbk. Bank Wakaf Mikro Honai Sejahtera Papua is the fourth BWM established through Astra's Corporate Social Responsibility (CSR) funds (OJK, 2020). Its establishment was facilitated by the Financial Services Authority (OJK). This Sharia LKM was established in the Islamic Boarding School in Yoka Village, Jayapura, namely the Ya Bunayya Islamic Boarding School.

The inauguration was held in April, and then there were 40 customers who had undergone the stages of forming the Community Business Group Around the Indonesian Pesantren (KUMPI), customers were formed in groups, at least 10 people, and each group lived in the same area (location). On January 22, 2020, BWM Honai Sejahtera has 130 (one hundred and thirty) cumulative customers with a minimum disbursement of 1 million rupiah which are shared (Saskia, 2020). Bank Wakaf Micro is able to provide a real example to the community in empowering the economy of micro entrepreneurs through increasing customer income. Based on the results of an interview with one of the customers, he stated that he greatly benefited from the provision of loan capital from BWM, because it really helps the business of selling pastries and hodgepodge that he has been doing at this time (Fajar, 2019). This shows that the government can provide a real example in the empowerment and development of micro-enterprises in Indonesian society. Because in it there is a good relationship between the three groups, namely the government, financial institutions and the community.

The purpose of this research is to analyze and describe the efforts of Bank Wakaf Mikro Honai Sejahtera Papua in increasing the income of the people of Heram District, and to analyze and describe the impact of the existence of Bank Wakaf Mikro Honai Sejahtera Papua on the economy of the community around the pesantren. 
The Efforts Of Sharia Micro Financial ...

\section{Literature Review}

\section{Sharia Micro Finance Institution}

Microfinance Institutions have developed until there are Islamic Microfinance Institutions (LKMS). Basically, Islamic microfinance institutions have a system that is almost similar, but the products and services and agreements (contracts) used are different. Compliance with Islamic sharia law for microfinance institutions includes the absence of usury, maisir, gharar, dharar, and taqdis. MFIs have a wide scope such as savings, loans, and payment services. As a loan institution, both for productive and consumptive activities, LKMS also functions as an intermediary institution in economic activities (Amri et al., 2017). Sharia Microfinance Institutions are institutions protected by law that have great potential in empowering the poor.

Products and services of Islamic Microfinance Institutions include micro savings, micro leasing, micro takaful (Amri et al., 2017). The contracts used in LKMS products and services are based on sharia principles which generally also exist in Islamic banking. The types of contracts commonly used in LKMS operations include financing (musyarakah and mudharabah), savings (wadiah and mudharabah), and buying and selling (murabahah) (Meuthiya, 2014).

\section{Micro Waqf Bank}

Bank Wakaf Mikro itself is a Sharia Microfinance Institution (LKMS) that focuses on financing small communities. In this case, OJK cooperates with the National Amil Zakat Institute (LAZNAS) in forming LKMS, each LKMS will receive around Rp. 3 billion to Rp. 4 billion from donors, where donors can come from all walks of life or companies with an initial fee of Rp. 1 million per person, however, the funds received by the LKMS will not all be channeled into financing, because some will be placed in the form of deposits in Islamic commercial banks. . In Islamic teachings, waqf functions to realize the potential and economic benefits of waqf property for the benefit of worship and to advance public welfare. This is in line with the objectives of the establishment of this Micro Waqf Bank, 
The characteristics of the Micro Waqf Bank lie in the companion process, the Micro Waqf Bank will first hold a selection for prospective customers, then train and mentor will be carried out as well as financing patterns made per group or "joint responsibility" scheme of the Micro Waqf Bank is financing without development with a maximum value of IDR 3 million and a profitsharing margin equivalent to 3\%. Financing through Micro Waqf Bank also without using interest (Lestari, 2019).

The Micro Waqf Bank business model is a service cooperative with a business license for a Sharia Microfinance Institution, provides financing using sharia principles, does not raise funds, low yields equal to $3 \%$ per year, without collateral, is provided with training and mentoring and is supervised by OJK and coordinates with Ministry of Cooperatives, Islamic Boarding Schools and Community Leaders (OJK, 2018).

Bank Wakaf Micro provides benefits such as providing training and business assistance to customers, increasing financial inclusion literacy, reducing inequality and poverty, providing business capital financing, implementing a pick-up system, avoiding moneylenders, and keeping away from interest (Sutera \& Kholis, 2019).

In its development, OJK continues to be committed so that Micro Waqf Banks can develop throughout Indonesia with the hope of improving people's lives and reducing inequality and poverty.

\section{Methods}

This study used qualitative research methods. Qualitative research methods are scientific ways of obtaining data for specific purposes and uses. Through research, humans can use the results to understand, solve and anticipate problems (Sujarweni, 2014). The author uses a case study approach aimed at discovering the phenomenon of Micro Waqf Bank efforts in helping communities to improve their economy.

Data analysis was carried out in this study using an analysis consisting of 3 activity paths that occur simultaneously, namely: (1) Data reduction is defined 
The Efforts Of Sharia Micro Financial ...

as the selection process, focusing attention on simplification, abstracting, and transformation of rough data that arise from written notes in the field. thus the data that has been reduced will provide a clearer picture and make it easier for researchers to collect data. (2) Better data presentation is a major means of valid qualitative analysis. Usually in the form of a brief description, chart, and sometimes in the form of narrative text. (3) Drawing conclusions at the end does not only occur during the data collection process, but needs to be verified so that it can really be accounted for (Sugiarto, 2017).

\section{Results and Discussion}

Based on the findings in the field, the efforts made by Bank Wakaf Mikro Honai Sejahtera Papua in increasing the income of the Heram District community include providing loans or financing in micro-scale businesses to the community, providing assistance, and providing business development consulting services to customers.

\section{Providing business capital loans}

The provision of business capital is given to the Heram District community through several stages and poses, including the identification stage, which is carried out by visiting the nearest sub-district to ask for data on the poor but they are productive or people who have the willingness and enthusiasm to work. For example, people who already have a small business or not but have a work spirit. In addition to visiting, customer identification can be done by visiting RT, RW, recitation women or other social groups.

After obtaining data from the local urban village, the next step is to carry out the socialization stage related to the micro-finance institution of the Micro Waqf Bank to the community, be it to recitation mothers or religious groups that are delivered at mosques and also visit community houses with give out brochures.

The due diligence phase is carried out by surveying prospective customers and selecting whether the prospective customer is by visiting the prospective customer's house and asking some questions related to their business. There 
Shimah Fauziah Yeubun, M. Anang Firdaus, Fachrudin Fiqri Affandy

are 4 criteria for assessing the feasibility of a prospective customer, including the house index, income index, asset index and land ownership index.

The stage before the compulsory group training (Pra PWK). This stage is carried out after the due diligence stage is carried out, prospective customers are then collected, notified and introduced to the Islamic microfinance institution Bank Wakaf Mikro, and notified about the regulations set for prospective customers this stage is carried out for 1 day.

Group Compulsory Training Stages (PWK). If the Pre-PWK stage has been completed and is feasible, it will be continued to the next stage, namely the compulsory group training stage which is carried out for 5 consecutive days. In this training, several materials will be given to prospective customers who are currently participating in the compulsory group training process. In this training, prospective customers will be tested with the accuracy of gathering time for 5 consecutive days. Prospective customers are required to arrive at the appointed time. If a member is late, this warning will be given so that the prospective customer and all group members are disciplined in time.

Thawing stage. After carrying out the compulsory group training stage as well as testing the group members. So immediately held a meeting between the manager and the board about prospective customers and their businesses. After obtaining approval from the management and management, the next step is to disburse the loan submitted by the customer. The disbursement is carried out in 3 stages because referring to the 2-2-1 system, this system means that what is disbursed first is the one who needs the most first with a line up backward so that the first disbursement is the last followed by the one in front of it and the last is the group leader or the chairman of KUMPI who had previously been deliberated and mutually agreed upon by its members.

The weekly halaqah stage or more familiarly known as the HALMI community is carried out once a week accompanied by the management of the Micro Waqf Bank with a maximum duration of 60 minutes per meeting. In the weekly halaqah meeting, the manager does not only focus on withdrawing 
The Efforts Of Sharia Micro Financial ...

installments but is interspersed with several deliveries related to religion or business development referring to the needs and desires of group members.

\section{Provide Assistance}

In providing assistance to the customers of Bank Wakaf Mikro, Honai Sejahtera Papua, it is carried out directly by the manager of the Micro Waqf Bank itself without involving other people. There are 3 (three) stages in providing assistance to customers, including improving the business economy, household management, and spiritual assistance.

Assistance related to economic improvement or customer business is carried out by always providing assistance to develop the business through entrepreneurship mentoring and mentoring, bookkeeping and service training, as well as training on access to capital and business expansion.

Spiritual assistance is provided in a way filled with religious studies by bringing in several ustadz from the Islamic boarding school yaa bunayya or usually filled in by the manager of the Micro Waqf Bank itself.

\section{Providing Marketing Facilities}

As stated by Mrs. Amelia as a customer of Bank Wakaf Mikro Honai Sejahtera Papua, which then the authors conclude that if the customer has produced a product, it is immediately processed by the officer and marketed online through social media and the official application of the Micro Waqf Bank, which includes a display of superior products produced by the customer. In addition to providing online marketing facilities to customers, Bank Wakaf Mikro also seeks to market superior products to customers during exhibitions and large-scale events held by the Financial Services Authority.

\section{Bank Wakaf Mikro Honai Sejahtera Papua}

The existence of Bank Wakaf Mikro Honai Sejahtera Papua as one of the first Islamic Microfinance Institutions (LKMS) in Papua is different from other microfinance institutions whose sources of funds come from banks, Bank Wakaf Micro gets an injection of funds from cash waqf from PT. Astra 
Shimah Fauziah Yeubun, M. Anang Firdaus, Fachrudin Fiqri Affandy

International TBK which is channeled through Bank Mandiri Syariah and subsequently provided and managed by Bank Wakaf Mikro Honai Sejahtera Papua. This waqf fund is financing with a minimum margin.

Community income in a simple sense is income which is an amount of money that is obtained or received from the community as remuneration from the production relationship of goods and services. An increase in income in a business activity carried out in a certain period is very important for every entrepreneur, with an increase in income, the business can be said to have experienced a positive development. Several things that are indicators of increasing income include employment opportunities, working capital and having a basis of business-related knowledge.

\section{The efforts made by Bank Wakaf Mikro Honai Sejahtera Papua in increasing the income of the people of Heram district}

In carrying out its efforts, Bank Wakaf Mikro Honai Sejahtera Papua Uses products and services of Micro Financial Institutions in the form of Non-Bank Financial Services which generally serve low-income households, including some who are quite vulnerable, Micro Financial Institutions combine financial and non-financial services to obtain greater benefits and reduce the risk of lending to the poor. These non-financial services are the closest MFI services and are needed by the community among low-scale economies.

Bank Wakaf Mikro Honai Sejahtera Papua has operated in accordance with institutional procedures, one of which is to provide financing using a qardh contract with the applicable legal basis, namely the National Sharia Council fatwa No: 19 / DSM-MUI / IV / 2001. In carrying out its role, BankWakaf Mikro Honai Sejahtera Papua strives to provide business capital loans, maximize mentoring, and provide marketing facilities for customer products. The Financing Program provided by officers to customers who have met the specified criteria using a group pattern consisting of 10-15 people in a group called the weekly halaqoh group or more commonly known as HALMI (Weekly Halaqoh) consists of several groups. 
The Efforts Of Sharia Micro Financial ...

The process when providing business capital loans to customers runs in several stages including through the identification stage, the socialization stage, the survey stage, the pre-compulsory group training (Pre PWK) stage, the compulsory group training (PWK) stage, the disbursement stage and the usual weekly halaqoh stages. called HALMI. Some of these stages become the terms and conditions for becoming a customer of Bank Wakaf Mikro Honai Sejahtera which aims to get customers who really want to get assistance in the form of business capital loans and customers who are responsible and trustworthy.

Business assistance is provided to customers every time there is a Halmi meeting by delivering materials on entrepreneurship, religion and providing motivation and encouragement to customers. There are also activities that involve group members such as sharing skills with one another so that fellow members who were only able to produce food products can produce very creative long-term products. In addition, the creative products produced by these customers will be given a place to market their products, namely the Micro Waqf Bank officers who will market them online or now known as sales on social media.

\section{The impact of the existence of Bank Wakaf Mikro Honai Sejahtera Papua}

The existence of the Honai Sejahtera Papua Micro Waqf Bank aims to improve the welfare of the community around the Islamic Boarding School which includes the people of Heram District, especially the welfare of the community in the economic sector by providing business capital loans, assistance to customers to improve their businesses, assistance is provided in 3 categories, namely, assistance through the provision of religious knowledge, household management, and entrepreneurship in community business development.

Bank Wakaf Mikro Honai Sejahtera Papua has 128 customers consisting of all women. They were invited to gather for the weekly halaqah meeting which is a routine activity that focuses on assisting in running a business to increase 
the income of the community around the boarding school. The following is the schedule for mentoring through HALMI activities.

The impact felt by customers during their use of Micro Waqf Bank products is that they feel greatly helped by the financing provided by the Micro Waqf Bank. Lots of customers, especially customers who are indigenous Papuans, feel very different from the existence of this Micro Waqf Bank, namely that they are very amazed at Muslims who sincerely help them achieve their economic welfare, feel that it is the first time they get a loan without any advantages, get business assistance and providing marketing facilities and increasing the knowledge that these Islamic boarding schools, which are the centers of Islamic religious learning, are able to help the government to prosper the small community through the household economy.

Financing received can finally be managed and become additional income. Where customers feel very significant benefits from starting to get loans without being given interest, are given regular assistance once a week by providing additional knowledge that is not known to customers, as well as providing motivation and providing solutions to business problems that the customer is running.

Previous research here is research that has been conducted by previous researchers who are relevant to the research plan that will be carried out by the author, including first, research conducted by Isnaini Harahap, Mailin, and Salisa Amina with the title Role of Sharia Micro Islamic Waqf Bank in Islamic Boarding School Mawaridussalam in economic empowerment. Public. The results of his research indicate the role of Micro Waqf Bank in Empowering the Community by providing business capital loans, releasing from the trap of moneylenders and the interest or usury system and adding religious knowledge that clearly provides community welfare. Second, research conducted by Muhammad Alan Nur with the research title Contribution of Micro Waqf Bank to Empowerment of Micro Businesses in Islamic Boarding Schools (Case Study of Al-Pansa Micro Waqf Bank). The results of his research suggest that it is known that the financing and business assistance carried out by Al-Pansa Micro Waqf Bank has an effect on an increase in the amount of 
production / total sales, operating income, operating profit, and economic conditions. Third, the research conducted by Jaka Sriyana with the title Research on the Role of BMT in Overcoming Poverty in Bantul Regency. The results of his research show that the increase in people's income in order to reduce the level of poverty is mainly caused by activities that are social, educational, and increased work motivation. and economic conditions. Third, the research conducted by Jaka Sriyana with the title Research on the Role of BMT in Overcoming Poverty in Bantul Regency. The results of his research show that the increase in people's income in order to reduce the level of poverty is mainly caused by activities that are social, educational, and increased work motivation. and economic conditions. Third, the research conducted by Jaka Sriyana with the title Research on the Role of BMT in Overcoming Poverty in Bantul Regency. The results of his research show that the increase in people's income in order to reduce the level of poverty is mainly caused by activities that are social, educational, and increased work motivation.

The conclusion from the results of the differences between the three previous studies and this study lies in the subject of the study where the previous research focused on empowerment and community welfare. While the focus of the author's subject is increasing people's income through the presence of Islamic Microfinance Institutions in the form of Micro Waqf Banks.

\section{Conclusion}

Based on the results of the above research, this study shows that the efforts of Bank Wakaf Mikro Honai Sejahtera Papua in increasing community income are carried out with several efforts including providing business capital loans given after the community follows several stages that have been determined by Bank Wakaf Mikro Honai Sejahtera Papua. The assistance provided by the Micro Waqf Bank is the holding of the Weekly Halaqah (HALMI) activity where during the activity several submissions will be given related to business development and religious knowledge along with the payment of installments. Granting of facilities is provided by marketing long-term customer products to 
Shimah Fauziah Yeubun, M. Anang Firdaus, Fachrudin Fiqri Affandy

official social media, as well as the official application of Bank Wakaf Mikro Honai Sejahtera Papua.

The impact of the existence of Micro Waqf Bank includes customers who feel very helped by the financing provided by the Micro Waqf Bank. The

AL-ARBAH | 96 financing they receive can be managed into additional income. the existence of Bank Wakaf Mikro Honai Sejahtera Papua also has an impact on increasing entrepreneurial knowledge on customers and has an impact on the spirituality of customers.

\section{References}

Afendi, A. (2018). Pengaruh Variabel Makroekonomi Terhadap Jumlah Penerimaan Zakat di Badan Amil Zakat Nasional (Baznas) Pusat Tahun 2012 - 2016. Muqtasid: Jurnal Ekonomi Dan Perbankan Syariah, 9(1), 54. https://doi.org/10.18326/muqtasid.v9i1.54-69

Amri, M., Widiyaningsih, \& Azizah, N. (2017). Lembaga Keuangan Mikro Syariah.

Badan Pusat Statistik. (2017). Presentase Penduduk Miskin September 2017 Mencapai 10,12 Persen. https://www.bps.go.id/pressrelease/2018/01/02/141/\%0APres entase-penduduk-miskin-september-2017-mencapai-10-12persen-html.\%0A

Fajar, S. (2019). Otoritas Jasa Keuangan Memperluas Bank Wakaf Mikro Ke Berbagai Daerah. https://www.wartaekonomi.co.id/read/ojkperluas-bank\%0Awakaf mikro-ke-berbagai-daerah\%0A

Ilahi, A. P., \& Afendi, A. (2019). Factors To Influence Employee Performance In Bank Tabungan Negara Sharia Semarang. ALARBAH: Journal of Islamic Finance and Banking, 1(1), 1. https://doi.org/10.21580/al-arbah.v1i1.4108

Lestari, I. D. (2019). Analisa Pengelolaan Produktif Melalui Bank Wakaf Mikro Dengan Pendekatan SWOT (Studi Emprisi LKM Syariah, El Manahij Lebak). Universitas Islam Negeri Syarif Hidayatullah 
The Efforts Of Sharia Micro Financial ...

Jakarta.

Meuthiya, A. A. (2014). Pengembangan Produk-Produk Lembaga Keuangan Mikro Syariah. Jurnal Equilibirium, 2(1). https://journal.ac.id/index.php/equilibrium/search/authors/vie w.

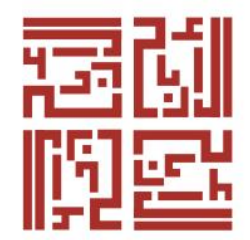

Noor, M. (2011). Pemberdayaan Masyarakat. Jurnal Ilmiah Civis, 1(2). https://journal.upgris.ac.id/index.php/civis/article/download

Penina, N. I. (2019). Komunikasi Pembangunan Melalui Pemberdayaan Masyarakat Untuk Pengentasan Kemiskinan. Jurnal Perspektif Komunikasi, https://jurnal.umj.ac.id/index.php/perspektif/article/view/5595 Saskia, B. P. (2020). Wawancara Pribadi.

Sugiarto. (2017). Metode Penelitian Bisnis. Andi Offset.

Sujarweni, W. . (2014). Metodologi Penelitian. Pustaka Baru Press.

Sutera, D. H., \& Kholis, R. (2019). Kebijakan Model Bank Wakaf Mikro Sebagai Solusi Pemberdayaan Ekonomi Masyarakat. Jurnal Law Reform, $15(2)$. https://ejournal.undip.ac.id/index.php/lawform\%0A/article/vie w. $\% 0 \mathrm{~A}$

Uci, J. (2018). Pemberdayaan Masyarakat Melalui Bank Wakaf Mikro. https://kompasiana.com/ucijunaedi/pemberdayaan-masyarakatmelalui-bank\%0Awakaf-mikro (diakses pada 20 Januari 2019).\%0A 
Shimah Fauziah Yeubun, M. Anang Firdaus, Fachrudin Fiqri Affandy

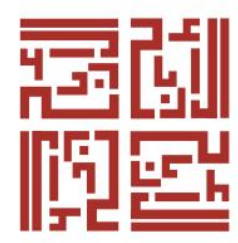

AL-ARBAH | 98 